\title{
Dissociation Constant (pKa) and Thermodynamic Properties of Some Tertiary and Cyclic Amines from (298 to 333) K
}

\section{Ali Tagiuri, Mohanned Mohamedali, Amr Henni*}

Clean Energy Technology Research Institute (CETRi), Faculty of Engineering and Applied Science, University of Regina, Regina, Saskatchewan S4S 0A2, Canada

\section{Supporting information}

Calculation of thermodynamic correction

$\left\{\right.$ Amine $\left.H^{+}\right\}=10^{(p H-14.004)}$

For $p H=10.39,\left\{\right.$ Amine $\left.H^{+}\right\}=2.43 \times 10^{-3}$;

Initial ionic strength of solutions are:

$I_{\text {initial }}=\frac{\left[V_{H C l}\right][\mathrm{HCl}]}{\left(V_{\text {Amine }}+V_{H C l}\right)}+\left\{\right.$ Amine $\left.H^{+}\right\}$

For $0.5 \mathrm{ml} \mathrm{HCl}(0.100 \mathrm{M})$ addition in $50 \mathrm{ml}$ aqueous amine solution, $I_{\text {initial }}=1.23 \times 10^{-3}$

$\gamma_{B H^{+}}=\frac{1}{10^{\left(\frac{A \sqrt{I}}{1+B a_{i} \sqrt{I}}\right)}}$

where, $\mathrm{A}=0.5092, \mathrm{~B}=0.3286$ at $298.15 \mathrm{~K}, a_{i}=4.5 \times 10^{-8} \mathrm{~cm}$.

For the addition $0.5 \mathrm{ml}$ at temperature $298.15 \mathrm{~K}$, the activity coefficient is $\left(\gamma_{\mathrm{BH}^{+}}\right)=0.96$.

$\left[\right.$ Amine $\left.H^{+}\right]=\frac{\left\{\text { Amine }^{+}\right\}}{\left(\gamma_{B H^{+}}\right)}$

For the addition $0.5 \mathrm{ml}$ at temperature $298.15 \mathrm{~K}$, the concentration of protonation amine is $\left[\right.$ Amine $\left.H^{+}\right]=2.53 \times 10^{-4}$

$I_{\text {true }}=\frac{\left[V_{H C l}\right][\mathrm{HCl}]}{\left(V_{\text {amine }}+V_{H C l}\right)}+\left\{\right.$ Amine $\left.^{+}\right\}$ 
The true ionic strength $\left(I_{\text {true }}\right)$ was estimated for $0.5 \mathrm{ml} \mathrm{HCl}$ addition at $298.15 \mathrm{~K}$ to be $1.24 \times 10^{-3}$

Then the thermal correction (TC) can be estimated as:

$T C=\frac{A z^{2} \sqrt{I}}{1+B a_{i} \sqrt{I}}$

The thermal correction (TC) subtracted from $\mathrm{pKa}$ value for $0.5 \mathrm{ml} \mathrm{HCl}$ addition at $298.15 \mathrm{~K}$ to the aqueous amine solution was to therefore equal to 0.02 . 